Est Ag 48 (2013) 401-434

\title{
Volver al Concilio Vaticano II: la centralidad de la Trinidad en las enseñanzas conciliares
}

\author{
Luis Ángel Montes Peral
}

RESUMEN: En su intento de vuelta a lo esencial, sorprende gratamente comprobar cómo el Concilio formula en sus múltiples documentos una y otra vez variadas descripciones en torno a la Trinidad, que nos llevan al pleno convencimiento de que precisamente la Trinidad Santa estuxo en la base de toda su rica reflexión teológica. Por eso el Vaticano II antes que eclesiológico fue un Concilio teológico, trinitario para precisar más. La presencia y actuación de la Trinidad se encuentra en la entraña misma de sus enseñanzas. Desconocerlo puede llevarnos a no indagar en lo más profundo que los padres conciliares quisieron legarnos como doctrina específica ofrecida a los creyentes. Se trata además de una realidad teológica mayor, llamada a ser reconocida en lo que vale, a constituirse en fundamento perenne de la nueva evangelización y también del cambio de paradigma en la transmisión de la fe, que necesitamos abordar en el presente con una gran urgencia.

PALABRAS CLAVES: Vaticano II, Padres Conciliares, Trinidad, Iglesia, documentos.

ABSTRACT: It is a pleasant surprise to discover that, in its attempt to return to what is essential, the Council formulates time and time again varied descriptions involving the Trinity in its many documents. This brings us to the clear conviction that it was precisely the Holy Trinity that was the basis for all the Council's wealth of theological reflection. That is why Vatican II, rather than being ecclesiological, was a theological Council, or to be more precise a Trinitarian one. The presence and action of the Trinity is to be found at the very heart of its teachings. To ignore this could lead one not to inquire into the most profound legacy of specific doctrine that the council fathers wanted to offer to believers. It is also a greater theological reality, destined to be recognized for its worth, to constitute a perennial foundation of the new 
evangelization and also of the paradigm shift in the transmission of faith, which we must today take on urgently.

KEYwORDS: Vatican II, fathers councilors, Trinity, Church, documents.

\section{Introducción necesaria: La vuelta a los orígenes}

Quizá la característica más dominante del Concilio fue la vuelta a lo esencial, el redescubrir los orígenes del cristianismo, en los que prenden nuestras raíces religiosas más específicas. Si el Concilio pretendió sobre todo beber de las fuentes primigenias, donde se encuentran los fundamentos de nuestra fe, no nos tiene que extrañar que la realidad divina, con todo lo que comporta como misterio trinitario, ha tenido una significación decisiva en las amplias y diferenciadas enseñanzas del Vaticano II.

Estamos ante este hecho fehaciente: las palabras que más aparecen en los textos conciliares son «Dios», «Padre», «Hijo», «Espíritu Santo», «Jesús», «Cristo», «Señor». Algo que debe hacernos pensar mucho, ya que esos documentos conciliares dejan buena constancia de la omnipresente presencia de la realidad divina en cada una de sus páginas y no sólo en las palabras, también en los conceptos, como vamos a demostrar aquí, al ofrecer algunos de los textos conciliares más significativos sobre el particular. Pretendemos mostrar efectivamente la importancia trascendental que la Trinidad jugó en su entramado teológico, cristológico, pneumatológico, antropológico, eclesiológico y sotereológico.

\section{Teología y eclesiología}

En una famosa conferencia de hace ya bastante tiempo sobre la aplicación del Vaticano II el entonces Cardenal Ratzinger expuso esta tesis de fondo:

«El Vaticano II quiso claramente insertar y subordinar el discurso sobre la Iglesia al discurso sobre Dios; quiso proponer una eclesiología en sentido propiamente teo-lógico, pero la acogida del Concilio hasta ahora ha omitido esta característica determinante, privilegiando algunas afirmaciones eclesiológicas; se ha fijado en algunas palabras aisladas, llamativas, y así no ha captado todas las grandes perspectivas de los padres conciliares». 
Esta misma idea la ha vuelto a expresar en su tiempo como Papa. En una de sus últimas apariciones públicas condensó así su pensamiento ante los sacerdotes de su diócesis romana:

«Alguien había criticado que el Concilio hablara de tantas cosas, pero no de Dios. ¡Claro que habló de Dios! Y fue su primer acto sustancial hablar de Dios y abrir a todo el pueblo santo, la adoración de Dios, en la celebración común de la liturgia del Cuerpo y Sangre de Cristo. En este sentido, más allá de los factores prácticos que desaconsejaban empezar de inmediato con temas controvertidos, fue -digamos- realmente un acto de la Providencia el hecho de que en los inicios del Concilio estuviera la liturgia, estuviera Dios, estuviera la adoración» (Discurso de Benedicto XVI a los párrocos y sacerdotes de la diócesis de Roma [14.02.13]: Ecclesia, números 3.666-67 [16 y 23 de marzo de 2013] 48).

\section{A la luz de la Trinidad y bajo su amparo Santísimo}

Otros han expresado esta misma idea con otros argumentos. No necesitamos presentarlos aquí, ya que este pequeño estudio quiere incidir precisamente en este mismo tema: en la centralidad del Dios Trinidad en los documentos conciliares; así mismo pretende ordenar los argumentos para probar la aseveración. Pero antes conviene adelantar la siguiente reflexión: Para entender la hondura de la Lumen Gentium, hemos de partir del hecho de que este texto no es primariamente eclesiológico, sino teológico. Propone sí una eclesiología, pero lo hace en un sentido marcadamente teológico. La Iglesia expresa y desvela su propio misterio, lo más sagrado de su identidad en la confesión trinitaria, ya que pervive en el tiempo por la voluntad salvífica del Padre Eterno, que la ha elegido como sacramento real, para salvar a todos los hombres, por la obra redentora del Hijo y por la acción santificadora del Espíritu Santo (capítulo primero).

La Iglesia es el «Pueblo de Dios» con todo lo que implica esta expresión en la Sagrada Escritura y en la teología (capítulo segundo). En modo alguno puede entenderse sin la expresa referencia a Dios, el objeto primero no sólo de la teología, también de la pastoral de la Iglesia. Ésta adquiere sentido en sí misma y tiene presente y futuro en la medida que toma conciencia de que lo más importante de su existencia descansa en el Altísimo y jamás puede prescindir de la Trinidad. De ahí que la perspectiva trinitaria constituya lo más decisivo de su esencia como la Familia del 
Padre, como el Cuerpo de Cristo, el Hijo, y como el Templo vivo del Espíritu Santo.

Teniendo en cuenta las observaciones anteriores, conviene salir del tedio espiritual, que asfixia algunas concepciones teológicas, que impiden vivir y testimoniar la alegría de la fe, el júbilo de la esperanza y el atractivo del amor practicado; virtudes necesarias para los tiempos de inclemencia, que sólo pueden darse, si la presencia y actuación de la Trinidad están a nuestro lado. La verdad del Evangelio, que sitúa al Padre, al Hijo y al Espíritu en el centro, tiene todos los ingredientes del verdadero progreso de la humanidad: está al lado de la vida en todos sus estadios, patrocina con ilusión los derechos humanos que se identifican con los mismos derechos de Dios. Esa verdad evangélica encuentra en Cristo al desvelador del auténtico rostro del Padre, el verdadero garante de todo lo que tiene que ver con la dignidad e intangibilidad de la persona humana.

\section{Modo concreto de proceder en este estudio}

Con las reflexiones siguientes se pretende llevar a cabo un ejercicio bien sencillo, pero que no deja de ser esclarecedor: queremos limitarnos a transcribir y comentar algunos textos trinitarios conciliares, primero de la Lumen Gentium, uno tan sólo por cada capítulo; después del resto de los documentos más significativos. Esta vez uno o dos textos por cada documento conciliar, aunque intentaremos que sean bien demostrativos de la tesis que hemos establecido aquí. Así comprobaremos, cómo el Concilio una y otra vez nos lleva a la entraña misma de nuestra religión, que no es otra que la Una e Indivisa Santísima Trinidad.

Procedemos de la siguiente manera: Después de la correspondiente cita, hago un pequeño comentario a los textos conciliares presentados, siempre con la intención de resaltar lo nuclear de lo expresado en ellos.

\section{EL DOCUMENTO CENTRAL: Lumen Gentium}

Donde más y mejor aparece que las enseñanzas conciliares llevan el sello trinitario es en la Constitución Dogmática sobre la Iglesia «Lumen Gentium» (LG), el documento central del programa teológico del Vaticano II. El dominico M. PHILIPON, perito conciliar y especialista en el tema trinitario, escribió certeramente en su día estas acertadas reflexiones programáticas: 
«Todas las enseñanzas del Concilio sobre el misterio de la Iglesia están marcadas con el "sello de la Trinidad". La naturaleza íntima de la Iglesia encuentra en el misterio trinitario sus orígenes eternos, su forma ejemplar y su finalidad. El Vaticano II ha tenido gran cuidado de indicarnos las múltiples relaciones del Dios-Trino con el Pueblo de Dios, con la jerarquía y con el laicado. Los problemas de la santidad de la Iglesia, del ecumenismo, de la escatología y del misterio mariano encuentran en la Trinidad su aclaración suprema. Todos los aspectos del misterio eclesial deben ser examinados a la luz de este misterio de los misterios. En Oriente como en Occidente, el culto cristiano se expresa bajo forma explícitamente trinitaria. Todo en la Iglesia se hace "en nombre y en honor de la indivisible Trinidad"» (G. BARAÚNA (dir.), La Iglesia del Vaticano II. Tomo I [Barcelona 31968] 341s).

Invito a leer el magnífico artículo de Philipon (págs. 341-363), que encaja perfectamente con mis planteamientos, aunque yo me atrevo a dar un paso más, desgranando de manera pormenorizada las declaraciones más significativas que se ofrecen en cada uno de los capítulos de la Constitución $L G$.

\section{Capítulo primero: La Trinidad y el misterio de la Iglesia}

Una observación inicial: este capítulo es el más trinitario de todo el Concilio, lo que significa mucho. Las tres definiciones paulinas sobre la Iglesia: Pueblo del Padre (LG 2), Cuerpo de Cristo, el Hijo Humanado (LG 3) y Templo del Espíritu (LG 4) muestran meridianamente claro, que la Iglesia encuentra su origen y razón de ser en la Trinidad con la estela salvadora que implica esta confesión. En efecto, depende esencialmente de la gracia trinitaria para poder llevar a cabo lo que su mismo nombre significa: asamblea reunida, así como para aceptar su vocación y para realizar su misión en el mundo: ser el alma de la sociedad. Sólo así será capaz de descifrar su misterio.

Esta constatación trinitaria fundamental se modula de tantas formas en las enseñanzas conciliares, que constituye la clave primera para poder entender y vivir la realidad referente a lo que es la Iglesia y qué significa en el mundo. A ella volveremos una y otra vez en las reflexiones que vayamos haciendo aquí. En este sentido, reflexionemos obre este significativo texto: 
«Consumada la obra que el Padre encomendó realizar al Hijo sobre la tierra (cf. Jn 17,4), fue enviado el Espíritu Santo el día de Pentecostés a fin de santificar indefinidamente la Iglesia y para que de este modo los fieles tengan acceso al Padre por medio de Cristo en un mismo Espíritu (cf. Ef 2,18). Él es el Espíritu de vida o la fuente de agua que salta hasta la vida eterna (cf. Jn 4,14; 7,38-39), por quien el Padre vivifica a los hombres, muertos por el pecado, hasta que resucite sus cuerpos mortales en Cristo (cf. Rom 8,10-11). El Espíritu habita en la Iglesia y en el corazón de los fieles como un templo (cf. 1 Cor $3,16 ; 6,19)$, y en ellos ora y da testimonio de su adopción como hijos (cf. Gal 4,6; Rom 8,15-16.26)» (LG 4a).

Imposible decir más acertadamente en tan pocas palabras lo que en realidad constituye «el misterio de la Iglesia», citando textos imprescindibles del Segundo Testamento. En nuestra espiritualidad necesitamos empezar por la acción del Espíritu en la vida eclesial y en su religiosidad propia, ya que «el Espíritu habita en la Iglesia y en el corazón de los fieles como un templo». Ese mismo Espíritu nos da a conocer a Jesús; además «ora y da testimonio de (nuestra) adopción como hijos». Los dos textos clásicos paulinos, que el Concilio cita, tienen aura de definitividad y nunca perderán su actualidad para la puesta en práctica de una espiritualidad de cuño cristiano. Qué duda cabe que la Trinidad determina esencialmente la identidad y la conciencia de la Iglesia, su oración y su acción, su experiencia y testimonio; en definitiva, cuanto es y hace.

\section{Capítulo segundo: La Trinidad y el Pueblo de Dios}

«La condición de este pueblo es la dignidad y libertad de los hijos de Dios (= del Padre), en cuyos corazones habita el Espíritu Santo como en un templo. Tiene por ley el nuevo mandato de amar como el mismo Cristo (el Hijo) nos amó a nosotros (cf. Jn 13,34). Y tiene en último lugar, como fin, dilatar más y más el reino de Dios (Padre), incoado por el mismo Dios en la tierra, hasta el final de los tiempos» (LG 9b).

Uno de los más positivamente revolucionarios textos conciliares es precisamente este segundo párrafo del número nueve. Tiene una construcción preciosa, adquiriendo pleno contenido en el protagonismo de la Trinidad, implícitamente afirmada:

Porque somos hijos del Padre, los creyentes gozamos de una dignidad inigualable. Nada semejante poseemos en nuestra existencia que pueda compararse a la gozosa conciencia de la filiación divina. Porque somos 
hijos del Padre y además nos inhabita el Espíritu Santo, contamos con la libertad verdadera, que nos permite actuar siempre para nuestro bien y en beneficio de los demás. Porque Cristo así nos lo enseñó y, lo que resulta aún más atrayente, así nos lo testimonió, estamos capacitados para amar del modo como Él lo hizo. Y el Señor lo hizo de veras, no de mentirijillas; llegando con su entrega hasta la muerte, una muerte por toda la humanidad y por cada uno de los hombres de los diversos tiempos de la historia.

Tres realidades mayores, definitivas recibe el Pueblo de Dios de la Trinidad: a) del Padre la filiación divina, que nos convierte en creaturas nuevas; b) del Hijo humanado el amor salvador, hecho testimonio y pasión; c) del Espíritu Santo la inhabitación gratificante, que nos conduce a la santidad y a la plenitud. Esas tres realidades recibidas graciosamente confluyen en lo mejor que tenemos en vertiente exterior: la dignidad inalienable, la igualdad universal y la libertad para el bien. Lo que nos puede llenar de admiración y gozo, de alabanza y agradecimiento.

«Así, pues, la Iglesia ora y trabaja para que la totalidad del mundo se integre en el Pueblo de Dios, Cuerpo de Cristo y templo del Espíritu Santo, y en Cristo, Cabeza de todos, se rinda al Creador universal y Padre de todo honor y gloria» (LG 17).

Con esta última confesión trinitaria se cierra este segundo capítulo, capital en las enseñanzas conciliares. Un observación conjunta de excepcional importancia se impone aquí: El Concilio esclarece su honda reflexión sobre la Iglesia: «designando la estructura trinitaria como fundamento de la última determinación de la Iglesia» (Josef Meyer zU SCHLOCHTERN). Sólo puede existir la Iglesia, cuando se la considera referida esencialmente a la Trinidad. Sin ella se esfuma la dignidad y libertad de los hijos de Dios, la ley de Cristo, el mandamiento nuevo del amor, la valencia fundante del reino. Sin ella no resplandece en la forma debida la dignidad inigualable e inalienable de la persona humana, en la que las diversas realidades teológicas se plasman y hacen verdad. Separar a la Trinidad de la Iglesia significa hacerla irrelevante.

\section{Capítulo tercero: La Trinidad y la jerarquía}

«El Espiritu Santo mantiene indefectiblemente la forma de gobierno que Cristo Señor estableció en su Iglesia. El Obispo, enviado por el Padre de familias a gobernar a su familia, tenga siempre presente ante sus ojos el ejemplo del Buen Pastor, que vino no a ser servido sino a 
servir (cf. Mt20,28; Mc 10,45) y a dar la vida por sus ovejas cf. Jn 10, 11» (LG 27bc).

La jerarquía constituye un servicio esencial en la Iglesia. Ésta no puede existir sin ella, porque así lo establece el Espíritu, señor y alma de la comunidad. También la jerarquía conserva una estructura trinitaria en lo más íntimo de su identidad y actividad. Representa al Padre en su oficio de regir la Iglesia. Su gobierno, de hecho, constituye un envío procedente de lo alto, para cumplir una misión necesaria en el seno eclesial. Pero en la puesta en práctica de este oficio tiene que tener la característica primordial, que acreditó el Hijo humanado en su paso por este mundo: convertirse en Buen Pastor al humanarse; no ser servido sino servir; dar la vida por sus fieles. Un gobierno que se aparta del servicio no puede contar con el beneplácito trinitario. El obispo ha de acreditarse como el primer servidor de la comunión diocesana.

«Ejerciendo (los presbíteros) en la medida de su autoridad, el oficio de Cristo, Pastor y Cabeza, reúnen la familia de Dios como una fraternidad, animada con espíritu de unidad, y la conducen a Dios Padre por medio de Cristo en el Espíritu» (LG 28a).

Quizá estas palabras sean las que contienen una mayor densidad doctrinal de todas las que el Concilio dirige a los presbíteros y que atañen a la entraña misma del cristianismo. Éste es ante todo y sobre todo la familia del Padre y la fraternidad del Hijo. Se realiza como comunión de hijos y cadena amorosa de hermanos, unidos en la gracia y en la tarea. El Vaticano II afirma con toda rotundidad que la Trinidad ha conferido a los presbíteros en el ejercicio de su ministerio una misión grandiosa e ilusionante: congregar en torno al Padre a su familia, hasta el punto de convertirla en una verdadera hermandad de vida y bienes, en la que reina la unidad y se realiza en el amor para testimonio ante el mundo.

Nada puede hacer avanzar más a la humanidad hoy que la puesta en práctica de una fraternidad abierta, en la que todos nos comportemos como hermanos y estemos dispuestos a practicar los valores de la justicia, la paz y la solidaridad, sobre todo con los más desprotegidos. Estas constataciones llenan de contenido la existencia sacerdotal, configurada por la caridad pastoral, en la puesta en práctica de su ministerio cotidiano.

El Espíritu Santo forma por dentro a los pastores de la Iglesia, llamados así a entregarse a fondo perdido a la comunidad, gobernando en nombre del Padre, y configurados como están con Cristo, Pastor y Cabeza en beneficio del Pueblo santo de Dios. La finalidad pastoral, tanto de los 
obispos como de los presbíteros, consiste en formar una familia de hijos y hermanos, de acuerdo con la voluntad del Padre y siguiendo los sentimientos del Hijo, plasmados en una práctica testimoniante durante su vida terrena. Familia llamada a dar testimonio de fraternidad delante del mundo, trasparentando así lo que la Trinidad espera de cada uno de nosotros y lo que los hombres de buena voluntad esperan de los creyentes.

4. Capítulo cuarto: La Trinidad y los laicos:

«Los laicos, en cuanto consagrados a Cristo y ungidos por el Espíritu Santo, son admirablemente llamados y dotados, para que en ellos se produzcan siempre los frutos ubérrimos del Espíritu. Pues todas sus obras, sus oraciones e iniciativas apostólicas, la vida conyugal y familiar, el cotidiano trabajo, el descanso de alma y cuerpo, si son hechas en el Espíritu, e incluso las mismas pruebas de la vida, si se sobrellevan pacientemente, se convierten en sacrificios espirituales, aceptables a Dios por Jesucristo (cf. 1 Pe 2,5), que en la celebración de la Eucaristía se ofrecen piadosamente al Padre junto con la oblación del cuerpo del Señor. De este modo, también los laicos, como adoradores que en todo lugar actúan santamente, consagran el mundo mismo a Dios» (LG 34b).

En un denso y singular párrafo el Concilio condensa la espiritualidad del laicado en sus rasgos esenciales. La espiritualidad es propia de todos los bautizados, no sólo de los ordenados o religiosos. También los laicos pueden -¡deben!- tener una relación íntima con la Trinidad, ya que han sido consagrados a Cristo, están ungidos por el Espíritu Santo, para que en la Eucaristía, raíz y centro de la existencia cristiana, puedan ofrecer al Padre sus propios cuerpos como oblación propia en comunión con el sacrificio salvador de Cristo. Estas realidades, con indudable fundamento trinitario, permiten a los laicos, conformar una vida santa de acuerdo con los designios divinos y consagrar el mundo a Dios, finalidad de su apostolado.

Conceptos centrales, con todo el hondo significado teológico y antropológico que implican, como «consagración», «unción», «ofrenda de la corporeidad», «consagración del mundo a Dios» configuran la identidad laical, proporcionan efectividad y fecundidad a su actuación en la Iglesia y confieren a sus personas consagradas y consagrantes una dignidad suma, siempre en estrecha comunión con la Trinidad. Habría que recordar y explicitar esa identidad sacerdotal con más frecuencia y, lo que resulta 
más importante, traducirla a la práctica en el seno de la comunidad y ante la sociedad.

Los laicos forman la porción más amplia del pueblo de Dios, que conviene valorar con la amplitud de miras pastorales, que han hecho los padres conciliares. En este sentido en la etapa postconciliar se ha ido desarrollando una importante teología del laicado con base trinitaria, que ha ayudado a reconocer el puesto del seglar en la vida y misión de la Iglesia, imprescindible para la ingente obra evangelizadora: «La nueva evangelización se hará, sobre todo, por los laicos, o no se hará» (CliM 148).

Las enseñanzas conciliares al respecto no pueden entonces quedar en bellas formulaciones, sino que tienen que descender a los hechos prácticos, vinculando la praxis laical con una fuerte y firme espiritualidad trinitaria. Tanto su consagración al Hijo Jesucristo, como su unción por el Espíritu Santo, con todàs las implicaciones inherentes, así como su ofrecimiento al Padre en la celebración de la Eucaristía, derivan sin duda del bautismo. Como el Padre envió al Hijo para la misión, así el Hijo humanado envía a los laicos a través de la Iglesia para que continúen la obra trinitaria en la ancha tierra; obra que no es otra que la salvación del mundo.

El sacramento básico por antonomasia, el bautismo como puerta de entrada necesaria para adherirse al cristianismo, sitúa a cada bautizado en una relación muy estrecha con las tres personas divinas, que le acompañará a lo largo de su vida, si es fiel a las promesas bautismales y las mantiene vivas en su andadura cotidiana con responsabilidad creyente. Lo que en realidad importa en la existencia cristiana es que la vivencia del bautismo se haga consciente y actuante, comprometida y testificante en la configuración permanente de lo cotidiano. Se puede vivir la vinculación trinitaria, auténtico fundamento del ser cristiano, con la verdad y fidelidad con que se viven los hechos de cada día. Nada más relevante para la existencia religiosa cristiana que dejarse dirigir por la gracia trinitaria.

5. Capítulo quinto: La Trinidad y la universal vocación a la santidad en la Iglesia:

«La Iglesia, cuyo misterio está exponiendo el sagrado Concilio, creemos que es indefectiblemente santa. Pues Cristo, el Hijo de Dios, quien con el Padre y el Espíritu Santo es proclamado "el único Santo", amó a la Iglesia como a su esposa, entregándose a Sí mismo por ella para santificarla (cf. Ef 5,25-26), la unió a Sí mismo como su propio cuerpo y la enriqueció con el don del Espíritu Santo para gloria de Dios (=Padre)» (LG 39). 
Propiamente santo sólo es Dios. Santidad, Soberanía y Amor con mayúsculas únicamente le corresponden a la Trinidad, formando una unidad complementada desde diferentes perspectivas. Pero por gracia divina, que quiere asociarnos a sus prerrogativas y a participar de sus dones, todos los que formamos el Pueblo de Dios estamos llamados a realizarnos en la santidad de los hijos y hermanos del reino. La Trinidad tiene a bien, porque así se muestra en la grandeza de su bondad, comunicarnos su Santidad, para que participemos activamente de ella. Somos santos entonces en la medida que nos vinculamos, en la forma que ya hemos señalado en otras ocasiones, al Padre, al Hijo y al Espíritu Santo, que siempre llevan la iniciativa en todo lo que tiene que ver con la salvación y la plenificación humanas. Nada mejor para ser santos, que imitar el amor del Padre, proseguir la obra salvadora del Hijo y dejarnos inundar de los carismas del Espíritu, puestos al servicio de nuestros hermanos los hombres.

No podemos desarrollar aquí el tema de los carismas, que tanto contribuyen a la adquisición de la santidad. Los padres conciliares hablaron con mucha competencia sobre ellos en algunos de los documentos centrales y pusieron de relieve su dimensión trinitaria. Remito a mi publicación: «Vivir en el Espíritu. El carisma presbiteral y su función respecto a los demás carismas»: Surge números 619-620 (2003) 382ss. En este largo artículo hay una primera parte general sobre los carismas, que puede ayudarnos a clarificar aquí dos realidades básicas: a) El protagonismo de la Trinidad en los carismas y de su esencial vinculación con ellos. b) La trascendencia que tienen para desarrollarse en la santidad mediante la construcción de la Iglesia y la extensión del reino de Dios.

6. Capítulo sexto: La Trinidad y los religiosos

«Todo el que ha sido llamado a la profesión de los consejos esmérese por perseverar y aventajarse en la vocación a la que fue llamado por Dios, para una más abundante santidad de la Iglesia y para la mayor gloria de la Trinidad, una e indivisible, que en Cristo y por Cristo es la fuente y origen de toda santidad» (LG 47).

Como ya hemos visto en el capítulo anterior, todos en la Iglesia estamos llamados a realizarnos en la santidad, cuya «fuente y origen» es la Trinidad Santa. Los religiosos perseveran en ella por un título especial y por un compromiso gozosamente asumido con libertad, consciencia, y responsabilidad, ya que profesan por voto los consejos evangélicos, que tanto ayudan en el crecimiento de la santidad mediante la práctica de la pobre$z a$, la castidad y la obediencia. Los religiosos acogen una vocación, que les 
vincula de por vida esencialmente con la santidad y les hace testigos de los dones celestiales. Su misión, orientada a convertir la vida religiosa en un signo vivo del carácter escatológico de la Iglesia, consiste en intensificar la santidad cada día como testimonio ante el mundo, para mayor gloria de la Trinidad.

Efectivamente, los religiosos dan cumplida gloria a la Trinidad Santa en la medida que viven de forma radical la existencia cristiana conforme a los designios divinos y la manifiestan ante los demás con la fuerza de la verdad y el arrastre del amor. Su vida está llamada a prefigurar en Cristo la escatología, en la que los bienaventurados no terminan nunca de tributar la acción de gracias y alabanza a Dios, porque tienen ya para siempre la vida plena. No sólo son testigos fuertes de la trascendencia, también de la ultimidad, a la que todos los hombres estamos llamados por gracia divina. Según esto, la Trinidad tiene especial trascendencia en la vida religiosa: ocupa el centro de su actividad, de modo que no se puede dar un paso en la vida religiosa sin la constante referencia explícita al Dios Trino y a lo que significa.

\section{Capítulo séptimo: La Trinidad y la plenificación escatológica}

«Unos peregrinan en la tierra; otros, ya difuntos, se purifican; otros, finalmente, gozan de la gloria, contemplando "claramente a Dios mismo, Uno y Trino, tal como es"; mas todos, en forma y grado diverso, vivimos unidos en una misma caridad para con Dios y para con el prójimo y cantamos idéntico himno de gloria a nuestro Dios. Pues todos los que son de Cristo por poseer su Espíritu, constituyen una misma Iglesia y mutuamente se unen en Él (Ef 4,16)» (LG 49).

En el apartado anterior ya hemos hecho referencia a la escatología, una dimensión imprescindible de la teología y espiritualidad cristianas. Ahora la hacemos objeto de nuestra reflexión directa, aunque sea de una manera muy breve y sencilla. Los que componemos la Iglesia militante o peregrina, como quiera llamarse, vivimos en comunión con la Iglesia triunfante; es más: estamos llamados también participar en su día de su misma felicidad imperecedera, que no pasa nunca. Esta esperanza cierta puede elevar la moral de los creyentes, que necesitamos siempre razones para poder seguir caminando, hasta alcanzar la bienaventuranza final. ¡Estamos llamados a vivir una vida feliz definitiva, unidos para siempre a la Trinidad, principio y fin de toda felicidad creada! ¡Lo deseado en el corazón humano tiene su verdadera correspondencia en la realidad trinitaria! 
Existe una sola Iglesia, identificada con Cristo, que se desarrolla en tres estados. El Concilio describe aquí esa tríada de estados diferentes, en que se encuentran los miembros de la Iglesia contemplados en su totalidad, sabiendo que existe una comunión muy estrecha entre la Iglesia celestial y la Iglesia peregrinante. A la Iglesia celestial pertenece tanto la Iglesia purgante como la triunfante. Lo decisivo consiste en tomar conciencia y vivir en consecuencia, que los creyentes estamos llamados a la felicidad plena, gozando como bienaventurados de la Trinidad y contemplándola tal como es en la medida que lo finito es capaz de lo infinito. ¿Puede haber destino más grande? ¿Una salvación más alta, que nos lleve a una felicidad tan plena?

\section{Capítulo octavo: La Trinidad y la Bienaventurada Virgen María}

«Queriendo Dios (Padre), infinitamente sabio y misericordioso llevar a cabo la redención del mundo, "al llegar la plenitud de los tiempos, envió a su Hijo, nacido de mujer..., para que recibiésemos la adopción de hijos" (Gal 4,4-5). "El cual, por nosotros y por nuestra salvación, descendió de los cielos y por obra del Espíritu Santo se encarnó de la Virgen María”»(LG 52).

Se trata de las palabras introductorias con las que empieza la mariología del Vaticano II, la más completa y rica emanada nunca del magisterio. El párrafo propuesto aquí sirve de encuadre general a cuanto se va a exponer a lo largo del rico capítulo. Lo que más llama la atención es que esas palabras sitúan a la Santísima Virgen María, Madre de Dios y Madre de los hombres, en íntima conexión con la Trinidad, como no podía de ser de otro modo. Se trata de toda una visión programática de la mejor mariología. Por encima de todo y antes de nada, María es la Hija predilecta del Padre, la Madre del Hijo y la Esposa fiel del Espíritu, que puso a disposición divina su cuerpo virginal, para que el Hijo de Dios pudiera tener un cuerpo humano y se convirtiera para siempre en nuestro hermano con todos los condicionamientos sociales, culturales y religiosos existentes en la condición humana. En ninguna persona humana como en ella ha penetrado sin limitación alguna la gracia del Espíritu. Su disponibilidad al Padre la eleva por encima del resto de las creaturas.

Estas afirmaciones aparecen una y otra vez en las reflexiones sobre el particular de los padres conciliares. Imposible entender nada sobre el privilegiado puesto de María en la historia de la salvación, su munus específico en la Iglesia, sin la referencia explícita e insustituible a la Trinidad. Y esa referencia convierte a la Madre del Hijo de Dios también en modelo 
perfecto del Cuerpo Místico de Cristo. Toda su dignidad y grandeza derivan de que es la Madre humana del Hijo del Padre por la acción creadora del Espíritu. Y esa es también la misión básica de la Iglesia: engendrar al Hijo de Dios en su seno y con la fuerza del Espíritu darle a conocer y testimoniarlo en la sociedad y ante el mundo, tan deseoso de salir de su desvalimiento y tan necesitado de auténtica salvación.

\section{REFLEXIÓN FINAL EN TORNO A LOS DATOS ANTERIORES}

Para entender a la Iglesia, Familia del Padre, Cuerpo del Hijo humanado y Templo vivo del Espíritu, primero hemos de acoger a la Trinidad en el corazón y reconocer con memoria agradecida sus maravillosas obras de amor. En la Iglesia la iniciativa procedente de la Trinidad resulta lo primero, con mucho lo más básico y principal que hay en su interior. Sólo introduciéndonos en ese protagonismo trinitario, cargado de fidelidad y amor; sólo extasiándonos ante sus múltiples obras maravillosas manifestadas de mil maneras; sólo agradeciendo lo que hace por cada uno de nosotros y por la humanidad entera, seremos capaces de entender el misterio de la Iglesia y los creyentes podremos así mismo comprendernos como auténticos hijos y hermanos queridos en el seno de la gran familia eclesial.

La Iglesia entonces es más que una organización, por bien estructurada y competente que parezca ante los ojos del mundo; es más que una institución por grande y eficiente que sea su utilidad pública; ante todo y sobre todo, ella misma se entiende como la familia querida del Padre, la gran obra del Hijo humanado, el organismo vivo del Espíritu, que con la fuerza salvadora, inherente en su interior, abraza a todos desde su raíz más íntima, para formar la gran familia de los hijos y hermanos y extender por doquier el reinado divino. Experimentar este acontecimiento en el interior significa tanto como descubrir lo que la Iglesia representa para los cristianos como Madre y Maestra, Discípula y Servidora, siempre desde el abrazo y la bendición de la Trinidad Santa.

La historia de la Iglesia constituye en realidad la historia de la Trinidad con su Amada, en la que se complace. La unidad interna de la Iglesia como Pueblo de Dios, Cuerpo de Cristo y Templo del Espíritu coincide con la unidad interna de la Trinidad, que recrea a su Amada a su imagen y semejanza y le conduce por los caminos de la santidad en la búsqueda de la plenitud escatológica. Mirando a la Trinidad la Iglesia se goza, 
reforma y transforma; obedeciendo sus mandatos, busca ser fiel a su vocación y corresponsable en la misión de forma fiel, continua y permanente.

La Iglesia, entonces, siempre e invariablemente está referida al $\mathrm{Pa}$ dre, al Hijo y al Espíritu. En las tres divinas personas encuentra el pleno sentido de lo que es, hace y está llamada a hacer. Mediante la Palabra y los sacramentos, mediante la acogida y la entrega por la fe la Trinidad nos abraza en el seno de la familia eclesial, de manera que se dirige a nosotros, se nos autocomunica con la fuerza desbordante de su amor y nos inunda con su generosa gracia, convertidos así en salvación y santificación. Todo esto lo somos - mejor, debemos serlo-, siempre que nuestra fe, acompañada de nuestro obrar, informa todo tanto nuestro ser, como el conjunto eclesial.

La entraña de la Iglesia, con todo lo que implica, se encuentra radicada entonces en la Trinidad Santa. De ella recibe cuanto de más valor posee: su existencia como tal y su actividad específica, su santidad y bienaventuranza final. Conforme a los textos explicitados aquí, queda perfectamente claro que la Trinidad se alza como la verdadera protagonista de la vida, vocación y misión de la Iglesia, de sus miembros y estados. Imposible imaginar, ni siquiera por un momento, a la Iglesia en lo que tiene mayor valor en ella, sin la bendita actuación salvífica del Padre, del Hijo y del Espíritu Santo en el modo y en la manera como los padres conciliares se han expresado con tanta veneración y exactitud.

La Iglesia no es nada sin la bienhechora actuación trinitaria, que nunca la ha dejado sola y a la que nunca dejará abandonada a su arbitrio. Lo es todo, cuando toma conciencia de su unión con la Trinidad y sigue obediente y fiel a sus designios salvíficos. Aquí la Iglesia puede orientarse en María, primera Iglesia e Iglesia plenificada. Los cristianos tenemos en la Madre de Jesús lo que la Iglesia es en su entraña más íntima, cuando se deja inundar por el amor y la gracia de la Trinidad y obra conforme sus designios salvadores.

Las constataciones anteriores llevan a los cristianos, hijos de la comunión eclesial, a la alegría, la gratitud y la acción de gracias, porque la buena noticia expuesta aquí no puede ser mayor: Los que formamos la Iglesia y participamos de su misión, tenemos una relación esencial con Dios, un vínculo indestructible con la Trinidad, un parentesco íntimo con la realidad divina, que nada ni nadie puede dinamitar, por mucho que se empeñe. Para los seglares, religiosos y jerarquía la Iglesia siempre será la comunidad reunida en torno al Padre y al Hijo y del Espíritu Santo y permanecerá en su conciencia como posesión del Padre, del Hijo y del Espíritu 
Santo. El corazón de la Iglesia late, cuando los creyentes proclamamos con verdad y sinceridad el nombre del Padre, del Hijo y del Espíritu Santo y vivimos conforme a sus designios santos de salvación, siendo testigos de la Trinidad Santa y Viva ante el mundo. Así estaremos en la mejor de las disposiciones para poder superar la tan traída y llevada «crisis de Dios». Así superaremos el «eclipse de Dios» con el atractivo de nuestro testimonio trinitario.

\section{LOS OTROS DOCUMENTOS DEL VATICANO II}

No sólo la Lumen Gentium, el resto de los documentos conciliares, unos de forma más explícita otros de manera implícita, giran en torno al misterio trinitario con todo lo que entraña de fuerza salvadora para la humanidad entera y para la Iglesia en sus distintas perspectivas. La dimensión trinitaria encaja perfectamente en el resto de los textos emanados del magisterio del Vaticano II. Desde el inicio al fin de las sesiones los padres tuvieron muy presente la actuación de la Trinidad en sus reflexiones en torno a los más diversos temas. La Iglesia está llamada a convertirse en una gran ventana, por la que permite salir la resplandeciente luz de la Trinidad al mundo necesitado de salvación. Fuera de la Trinidad Santa no puede haber salvación auténtica y completa. Presentamos ahora el resto de las Constituciones por la importancia básica que tienen en el desarrollo y plenificación del pensamiento conciliar en torno al tema que nos ocupa.

\section{Gaudium et Spes}

Hemos contemplado a la Iglesia en sí misma y comprobado cómo lo más hondo de su realidad íntima consiste en ser familia del Padre, Cuerpo de Cristo y Templo vivo del Espíritu Santo. Ahora queremos seguir contemplando a la Iglesia, pero en su relación con el mundo y en su misión ante la sociedad, en la que está inserta, de modo que «los gozos y esperanzas, las angustias y tristezas de los hombres de nuestro tiempo, sobre todo de los pobres y de cuantos sufren, son a la vez gozos y esperanzas, tristezas y angustias de los discípulos de Cristo. Nada hay verdaderamente humano que no encuentre eco en su corazón» (Inicio de la GS). 
Una observación salta enseguida: también esta Constitución Pastoral proyecta una y otra vez el esquema trinitario en el tratamiento de sus temas, como vamos a comprobar en algunas calas, que queremos efectuar:

«L a comunidad cristiana está integrada por hombres que, reunidos en Cristo, son guiados por el Espíritu Santo en su peregrinar hacia el reino del Padre y han recibido la buena nueva de la salvación para comunicarla a todos. La Iglesia por ello se siente íntima y realmente solidaria del género humano y de su historia» (GS 1).

La Iglesia no tiene un fin en sí misma. Reunida por el Hijo, conforme a los designios del Padre, y guiada por el Espíritu, no vive para mirarse a sí misma; más bien se siente unida y solidaria con la humanidad. Su finalidad consiste en anunciar la buena noticia de salvación, porque tiene de su parte el amor trinitario, que le impele no sólo a comunicar la salvación sino a unirse a ella, de modo que pueda hacerse realidad en todos, siempre testimoniando su destino escatológico. Una de sus tareas mayores y de las más gratificantes consiste en buscar la comunicación y hasta la comunión real y efectiva con el mayor número de hombres, independientemente de su raza, pueblo o condición y mostrarles más con el propio testimonio que con la palabra lo que significa la salvación en lo concreto de las personas.

En efecto, «nacida del amor del Padre Eterno, fundada en el tiempo por Cristo Redentor, reunida en el Espíritu Santo, la Iglesia tiene una finalidad escatológica y de salvación, que sólo en el siglo futuro podrá alcanzar plenamente» (GS 40b). Mientras tanto, «experimenta la suerte terrena del mundo, y su razón de ser es actuar como fermente y alma de la sociedad, que debe renovarse en Cristo y transformarse en familia de Dios» (GS 40b). En la puesta en práctica de su misión y servicio, está llamada a ser el alma de la sociedad, de manera que ayude a hacer de la humanidad la gran familia de Dios, que vive la paz.

«La paz sobre la tierra, nacida del amor al prójimo, es imagen y efecto de la paz de Cristo, que procede de Dios Padre. En efecto, el propio Hijo encarnado, Príncipe de la paz, ha reconciliado con Dios a todos los hombres por medio de su cruz, $y$, reconstituyendo en un solo pueblo y en un solo cuerpo la unidad del género humano, ha dado muerte al odio en su propia carne y, después del triunfo de su resurrección, ha infundido el Espíritu del amor en el corazón de los hombres» (GS 78c). 
Tanto los temas doctrinales (primera parte de la Constitución) como los pastorales (segunda parte), que abordan los problemas más candentes y urgentes también de hoy, encuentran su asiento en la Trinidad. No hay paz, justicia y desarrollo de los países del Tercer Mundo sin la referencia explícita al amor del Padre, la salvación del Hijo y la santificación del Espíritu Santo. La Iglesia puede salir al mundo con garantías, aunque el éxito a corto plazo nunca esté asegurado, cuando se entiende como la familia del Padre, convertida en «luz del mundo», «sal de la tierra», «fermento en la masa» y servidora de la reconciliación, la justicia y la paz, entendiéndose así como «sacramento universal de salvación». La identidad de la Iglesia, su naturaleza más íntima tiene que ver con su comunión con la Trinidad, que le lleva a amar a la humanidad y salir al mundo con afán de regenerarlo.

La humanidad necesita la paz, para que los hombres de buena voluntad puedan desarrollar sus posibilidades y para que los pueblos en su conjunto vayan estableciendo relaciones más fraternales. Esa paz, uno de los mayores dones de los que los hombres podemos gozar, proviene de muy diversas formas de la Trinidad y los creyentes sabemos muy bien que sólo cuando contamos con la gracia divina y con la colaboración generosa humana puede ir haciéndose realidad. Trabajar por la paz es lo que la Trinidad quiere para todos los hombres, porque nos ha creado no para vivir como enemigos sino como amigos, incluso como participantes de una misma familia con un destino común. La paz nace del amor y de la reconciliación que nos ha alcanzado el Hijo encarnado con su muerte y resurrección. Y es el Espíritu del amor el que la infunde en el interior de los hombres y la impulsa en los diferentes pueblos de la tierra. No se puede alcanzar la paz sin la referencia a Dios y a sus dones, sin que el hombre tome conciencia de la vocación a la que ha sido llamado; vocación al amor, la unidad y la concordia.

La Trinidad constituye entonces el verdadero fundamento de la dimensión antropológica y social. Orienta al hombre y a la sociedad hacia el gran don de la paz en el mundo. Y así la Iglesia, movida por la actuación anterior, invita a los esposos a imitar el amor trinitario en la intimidad familiar. El Concilio no sólo contempla la vida intratrinitaria como el modelo supremo de cuanto está llamada a ser la Iglesia, también de lo que debe ser el hombre, incluida la familia, célula básica de toda sociedad sana. 


\section{Dei Verbum}

Se trata de uno de los documentos mayores del Concilio, ya que tiene la máxima calificación de "Constitución Dogmática», como la LG. La Palabra de Dios también ofrece una estructura trinitaria: En su origen procede del Padre, encuentra su asiento humano en el Hijo y es percibida bajo la acción del Espíritu. Todo nace del asombro inicial, que supone salir la Trinidad al encuentro del hombre, dotado como el mismo Dios de palabra. De hecho la revelación lo es todo en el cristianismo. El camino del amor pasa siempre por la revelación, la comunicación y la comprensión.

Quiso el Padre, que «habla a los hombres como amigos», "con su bondad y sabiduría, revelarse a Sí mismo y manifestar el misterio de su voluntad (cf. Ef 1,9): por Cristo, la Palabra hecha carne, y con el Espíritu Santo, pueden los hombres llegar hasta el Padre y participar de la naturaleza divina (cf. Ef 2,18; 2 Pe 1,4)» (DV 2).

«La Iglesia siempre ha venerado la Sagrada Escritura, como lo ha hecho con el Cuerpo de Cristo, pues sobre todo en la sagrada liturgia, nunca ha cesado de tomar y repartir a sus fieles el pan de vida que ofrece la mesa de la Palabra de Dios y del Cuerpo de Cristo. La Iglesia ha considerado siempre como suprema norma de su fe la Escritura unida a la Tradición, ya que, inspirada por Dios y escrita de una vez para siempre, nos transmite inmutablemente la palabra del mismo Dios; y en las palabras de los Apóstoles y los Profetas hace resonar la voz del Espíritu [...]. En los Libros sagrados, el Padre, que está en el cielo, sale amorosamente al encuentro de sus hijos para conversar con ellos» (DV 21).

No podemos entender lo más sagrado de la Palabra de Dios, palabra de verdad y vida para los seguidores de Jesús, sin contar con el protagonismo supremo de la Trinidad en pleno. En la Sagrada Escritura no sólo contamos con la Palabra con mayúscula, el mismo Padre establece con nosotros un diálogo de amor, en ella el Hijo humanado se ofrece, junto con su Cuerpo, como pan de vida y resuena la voz del Espíritu, que quiere transformar el corazón humano y unir a los hombres a Dios.

Lo más hermoso de la Palabra de Dios consiste en que en ella se nos revela el verdadero rostro divino: que se despliega como Padre, Hijo y Espíritu Santo. Se nos dona un Dios en una trinidad de personas, que nada tienen que ver con el rencor, la venganza, la ira incontrolada, sino con el amor, la misericordia y el cariño de un Dios, que sale a la búsqueda del hombre con su misteriosa iniciativa, que nunca deja a sus criaturas en la 
estacada. Quiere posesionarse de cada uno de nosotros con los lazos del amor y desea que lleguemos a la felicidad.

El Padre no sólo es Padre del Hijo, también lo es de cada uno de nosotros y desea relacionarse con cada uno de nosotros, hablándonos como a amigos. El Hijo no sólo es el Hijo del Padre, del mismo modo es hermano nuestro y nos ha descubierto al Padre como es y se comporta. El Espíritu Santo no es solo el Espíritu del Padre y del Hijo, viene en ayuda del espíritu humano y lo eleva al ámbito de lo divino.

He aquí la buena noticia, llamada a encontrar eco en el corazón humano: La Trinidad ha hablado. No ha querido permanecer en el silencio eterno, como muy bien podía haber hecho. Ha puesto todo su interés en dirigirse a los humanos a través de la Palabra, que podemos acoger y entender, porque corresponde por entero a nuestra manera de ser y se adapta a nuestras capacidades cognoscitivas, volitivas e intelectivas. Lo ha hecho entonces respetando escrupulosamente los comportamientos inherentes a la propia condición humana. Por pura gratuidad la Trinidad Santa ha querido establecer un diálogo de amor con nosotros en la forma de conversación entrañable.

\section{Sacrosanctum Concilium}

«Así como Cristo fue enviado por el Padre, Él a su vez envió a los Apóstoles, llenos del Espíritu Santo. No sólo los envió a predicar el Evangelio a toda criatura y a anunciar que el Hijo de Dios, con su muerte y resurrección, nos libró del poder de Satanás y de la muerte y nos condujo al Reino del Padre, sino también a realizar la obra de la salvación que proclamaban mediante el sacrificio y los sacramentos, en torno a los cuales gira la vida litúrgica» (SC 6).

El lugar privilegiado, donde se realiza la salvación tanto personal como comunitaria, es en la liturgia, en lo que tiene de celebración festiva y actualización eficaz de los misterios divinos de salvación. La liturgia, fiesta de la fe, encuentra su centro y punto culminante en la Trinidad salvífica. Para la Iglesia orante constituye el momento mayor de la experiencia de la Trinidad, que se concreta del modo más alto y real en la celebración de la Eucaristía, motor de la liturgia y cumbre de los sacramentos. La relación de la Eucaristía con la Trinidad ofrece una intimidad, digna de ser destacada, en las plegarias eucarísticas, dirigidas al Padre en el Hijo mediante la acción del Espíritu. 
El Concilio dio un impulso decisivo para la adecuada composición de las plegarias eucarísticas, aptas para ser recitadas en la celebración de la Eucaristía, centrada en el misterio pascual. Sobre todo la plegaria tercera desarrolla una bellísima estructura trinitaria de gran densidad espiritual. Merece la pena meditarla despacio, para admirar, valorar y saborear todos sus contenidos teológicos. Caer en la cuenta del tesoro, que encierra en sí misma esta plegaria, puede ser una forma muy apta de celebrar bien la Eucaristía. Sentirse llamados, «tocados» e interpelados por el Padre, el Hijo humanado y el Espíritu representa la cúspide de la acción liturgia con todo lo que representa.

\section{Ad Gentes}

Para no alargar nuestro trabajo nos reducimos a presentar ahora tres decretos conciliares de los más significativos, por tener una especial incidencia en la pastoral concreta de las iglesias locales. Nuestra tesis quedará así lo suficientemente corroborada en sus múltiples puntos de vista.

Empezamos por el primero de los elegidos: el famoso Decreto sobre la actividad misionera de la Iglesia «Ad Gentes» (AG), que entre los decretos tiene la mayor orientación trinitaria. Parte de estos dos principios:

«En el orden actual de cosas, del que están surgiendo nuevas condiciones para la humanidad, la Iglesia, sal de la tierra y luz del mundo, se siente llamada con mayor urgencia a la obra de la salvación y renovación de toda creatura, para que todas las cosas sean instauradas en Cristo y en Él formen los hombres una sola familia y un único Pueblo de Dios» (AG 1a).

«La Iglesia peregrinante es, por su naturaleza misionera, puesto que toma su origen de la misión del Hijo y de la misión del Espíritu Santo, según el propósito de Dios Padre» (AG 2a).

La Iglesia peregrinante pone sus ojos en la Trinidad y toma plena conciencia que su actividad misionera encuentra su origen fundante y recibe su impulso de las misiones trinitarias. $\mathrm{Y}$ así los primeros números del primer capítulo, que establecen los principios doctrinales del decreto, nos hablan de los designios salvadores del Padre (AG 2), de la misión del Hijo (AG 3), de la misión del Espíritu Santo (AG 4), para luego hablar de la misión de la Iglesia (AG 5), que fiel a los designios divinos prolonga en el tiempo las misiones divinas, con todo la carga salvífica que comportan. 
Sólo así, teniendo a la Trinidad como modelo perfecto para su actuación, llevará a buen puerto su actuación misionera (AG 6).

Los padres conciliares nos ofrecen aquí toda una enseñanza dinámica en torno a la llamada "Trinidad Económica», es decir: la Trinidad en relación con el modo concreto de realizarse la salvación, que tiene que ver mucho con la misión. Baste leer los seis primeros números para darse cuenta de la fecundidad, que trae consigo para la humanidad entera y especialmente para los creyentes, el desbordamiento del amor trinitario en la creación, sobre todo la humana. Conviene leer con atención y reposo esos números. Se entienden perfectamente, conviene rezarlos, acogerlos gozosamente y llevarlos en la práctica con el debido testimonio de vida y la correspondiente responsabilidad. Estos números constituyen enseñanzas fundantes; desde el punto de la vista teológico, de las más ricas emanadas del magisterio conciliar.

\section{Apostolicam Actuositatem}

«El apostolado se ejercita en la fe, en la esperanza y en la caridad que el Espíritu Santo difunde en el corazón de todos los hijos de la Iglesia. Más aún, el precepto de la caridad, que es el mandamiento máximo del Señor, urge a todos los cristianos a procurar la gloria de Dios (Padre) por el advenimiento de su reino y la vida eterna a todos los hombres, a fin de que conozcan al único Dios verdadero y a su enviado Jesucristo (cf. Jn 17,3)» (3b).

La estructura trinitaria no resulta aquí tan explícita como en otras ocasiones. Pero se deduce con facilidad, de modo que podemos afirmar que los fundamentos del apostolado seglar se encuentran en la presencia y actuación de la Trinidad. Efectivamente, para ejercer el apostolado los seglares necesitan la concurrencia en su vida de las tres virtudes teologales, que tienen su objeto en Dios. El encargado de infundirlas es el Espíritu Santo. No puede darse verdadero apostolado sin la práctica de la caridad, el mandamiento máximo establecido por el Hijo humanado, convertido en nuestro Señor por la práctica de un amor hasta el final, hasta el último suspiro de vida.

Precisamente ejercitando el apostolado los fieles procuran la gloria de Dios Padre (cf. inicio del número 2: «La Iglesia ha nacido con este fin: propagar el reino de Cristo en toda la tierra para gloria de Dios Padre»). Y en realidad esa gloria consiste en que el hombre viva y participe de la redención salvadora. El Padre bueno recibe de verdad gloria en la medi- 
da que transmite vida abundante a los hombres, a todos los hombres, ya que «quiere que todos se salven» (1 Tim 2,4). Lo más vivo y auténtico, lo más eficaz y fecundo, que trae consigo el apostolado de los seglares, encuentra su origen e impulso en la Trinidad. La vida que proporciona, proviene del Padre; la caridad con que se practica en su ejercicio específico, nos la enseñó y testimonio el Hijo humanado; y las virtudes que vivifican su eficacia, tienen a su protagonista en el Espíritu, Señor y Dador de vida.

\section{Presbyterorum Ordinis}

«El Señor Jesús, a quien el Padre santificó y envió al mundo (Jn 10,36), hace partícipe a todo su cuerpo místico de la unción del Espíritu con que fue Él ungido, pues en él todos los fieles son hechos sacerdocio santo y regio, ofrecen sacrificios espirituales a Dios por Jesucristo y pregonan las maravillas de Aquel que de las tinieblas ha llamado a su luz admirable (1 Pe 2,5.9)» (PO 2)

«Los presbíteros, por la sagrada ordenación y misión que reciben de los obispos, son promovidos para servir a Cristo, Maestro, Sacerdote y Rey, de cuyo ministerio participan, por el que la Iglesia se edifica incesantemente como Pueblo de Dios (= Padre), Cuerpo de Cristo (= Hijo) y Templo del Espíritu Santo» (PO 1).

Por obra y gracia de la Trinidad el pueblo de Dios está vocacionado para realizarse en la dignidad sacerdotal, en lo que tiene de más vivo y verdadero. Por Jesucristo está capacitado para ofrecer sacrificios espirituales mediante una vida santa como alabanza incesante a Dios. Pero esto no resta una pizca de verdad al hecho de la existencia de un sacerdocio jerárquico, puesto al servicio del pueblo de Dios, que en su totalidad constituye un pueblo real, profético y sacerdotal.

Ese sacerdocio jerárquico, también llamado ministerial, porque está al servicio del pueblo de Dios, ofrece una clara vertiente trinitaria. Su misión específica consiste en congregar al Pueblo del Padre en nombre de Cristo, integrarse con un carisma especial en el Cuerpo del Hijo y dejarse inhabitar por el Espíritu en orden a presidir la comunidad y llevar los carismas de los fieles a la unidad eclesial, para mayor gloria de Dios y para la extensión de su reino. 


\section{DOCE CONCLUSIONES}

Al llegar al final de estas reflexiones, resumimos cuanto hemos expresado aquí en una docena de conclusiones, que nos pueden ayudar a presentar las enseñanzas centrales del Vaticano II en torno al tema abordado hasta aquí.

\section{EN LA RAIZZ MISMA DE LA IGLESIA}

Los padres conciliares fundamentaron todas las realidades teológicas de sus variadas reflexiones en la Trinidad, el auténtico Dios vivo y verdadero, que diferencia al cristianismo del resto de las religiones, ya sean monoteístas o politeístas. «El esquema trinitario - del Padre al Padre por el Hijo en el Espíritu Santo - constituye uno de los motivos teológicos más frecuentes *del Vaticano II» (I. CONGAR, «El papel de la Iglesia en el mundo de hoy», en A.A. V.V., La Iglesia en el mundo de hoy II [Madrid 1970; Taurus] 392ss). «Más frecuente», sí, pero también «más hondo y radical», ya que llega a su raíz primigenia por antonomasia. Tal esquema domina en la Lumen Gentium y surge, una y otra vez, en el resto de los documentos del Concilio, como hemos tenido la oportunidad de mostrar con textos concretos bien demostrativos y significativos.

Pero hay algo más hondo aún: Las afirmaciones más básicas y esenciales de las enseñanzas doctrinales de los padres conciliares tienen que ver con Dios, que es siempre y sin excepción lo primero, lo más importante y lo definitivo tanto en la visión de la realidad entera como en la consideración de la humanidad en su relación con la trascendencia. En este sentido la Trinidad se alza como el origen, centro y plenitud de todos los restantes contenidos religiosos: de la cristología y pneumatología, de la eclesiología y sacramentología, de la antropología y la sotereología. Sin la realidad trinitaria todo su edificio doctrinal se derrumbaría; no se podría entender, ni deducir nada de lo que en el cristianismo es esencial, prioritario, permanente, consistente y decisivo.

De hecho la Trinidad Santa constituye la base inconmovible tanto de la fe de la Iglesia como de todo su planteamiento doctrinal y entramado pastoral. Tal como hemos mostrado de forma suficiente, presentando textos significativos sobre el particular, la Trinidad, con cuanto conlleva de realidad vivificante y salvadora, estuvo omnipresente en todos los documentos conciliares de modo altamente significativo, como no podía ser por menos. Por eso podemos afirmar que la Iglesia, que peregrina por todos 
los espacios de la tierra y atraviesa todos los tiempos históricos, siempre permanece la misma en lo que tiene de más sagrado: su naturaleza y razón de ser están erradicadas en la Trinidad, fuente de toda su vitalidad. La vida y el destino eclesiales descansan en el regazo trinitario. De la Trinidad Santa recibe la Iglesia la fuerza de su gracia, para cumplir su misión y prestar su testimonio de amor en la sociedad y ante el mundo.

El Concilio, apoyándose en la tradición viva de la Iglesia sobre la Trinidad y sin necesidad de tener que reformular ningún aspecto básico en relación con el dogma trinitario, sitúa su misterio salvífico en el centro preciso de todas sus reflexiones. Al mismo tiempo establece de forma dinámica la relación de la Trinidad con la humanidad, con la Iglesia y con los creyentes tanto en su dimensión personal como comunitaria. La Trinidad está en el origen del cosmos y de la humanidad; en la regeneración y plenificación de los hombres. No puede darse vida cristiana, ni espiritualidad, ni salvación que se precie al margen de la Santísima Trinidad. No cabe duda que hoy existen muchos problemas que la Iglesia está llamada a iluminar y atender, incluso a solucionar en la medida de sus posibilidades. Pero en modo alguno puede permitir que quede oscurecida la centralidad de la fe cristiana, que consiste en el encuentro con la Trinidad mediante Jesús de Nazaret, la experiencia del amor divino y humano, así como la esperanza en la otra vida plenificada. El Concilio vuelve una y otra vez a estos temas desde el principio trinitario por la importancia decisiva que tiene en la existencia en Cristo, núcleo del cristianismo.

\section{UNA ECLESIOLOGIA TEOLÓGICA}

El pensamiento del Concilio Vaticano II, como es bien sabido y es repetido con frecuencia, se centró en la Iglesia, considerada en sí misma primero; y en su relación con el mundo y la sociedad después. En este sentido las constituciones Lumen Gentium y Gaudium et Spes constituyen el gozne dogmático y pastoral, alrededor del cual giran todas sus enseñanzas, focalizadas en la honda espiritualidad eclesial y en la salida al mundo actual. Siguiendo estos postulados metodológicos no desarrolló una doctrina sobre la Trinidad de forma sistemática; cosa que aquel momento histórico no precisaba en modo alguno.

No estaba dentro de sus planteamientos abordar directamente el tema en cuestión, ya tratado de manera suficiente en otros concilios, aunque siempre se puede expresar algo nuevo en el tratamiento de su enseñanza, ya que la realidad de la Trinidad siempre sorprende en teoría y pra- 
xis. Pero esto no quiere decir que los padres no se dieran perfecta cuenta, que no se puede considerar la Iglesia, si no es manteniendo a la vista el amplio horizonte trinitario. Por eso resulta imposible hablar de manera relevante de la Iglesia, si se prescinde de su auténtico protagonista en ella, el Dios Unitrino. En la existencia cristiana nada puede fructificar sin la Trinidad, que conforma por dentro la entraña de la teología y está llamada a permanecer en el corazón mismo de la espiritualidad cristiana, fecundando el ser y quehacer de los creyentes tanto en la Iglesia como en el mundo.

En este sentido tiene razón J. RATZINGER cuando afirma que: «el Concilio Vaticano II no fue sólo un concilio eclesiológico, sino ante todo y sobre todo, habló de Dios - y no solamente dentro de la cristiandad, sino también dirigiéndose al mundo-, del Dios que es Dios de todos, que salva a todos y es accesible a todos». Y lo hizo mediante una concreción aún mayor, que no he querido dar por probada, sino que me he esforzado por proponerla paso a paso con textos conciliares bien claros y con las correspondientes reflexiones acerca de ellos. El Dios del Concilio es el Dios Trinidad, revelado en Cristo y propuesto a la humanidad entera a través de la fe de la Iglesia. Y precisamente ese Dios ocupa el lugar más destacado en todas las reflexiones de los padres conciliares, siendo proclamado una y otra vez en su especificidad trinitaria, la original del cristianismo.

\section{CRISTOLOGIA Y PNEUMATOLOGIA AL SERVICIO DE LA TRINITARIOLOGIA}

En el intento preciso de centrar debidamente este estudio, hemos prescindido de desarrollar de forma explícita la cristología y la pneumatología, para abordar directa e inmediatamente la trinitariología. Sobre todo en las cuatro grandes Constituciones existen números programáticos sobre Jesucristo de gran densidad doctrinal, que se han repetido en el postconcilio hasta la saciedad. Algo semejante podemos afirmar del Espíritu Santo. Reduciéndonos aquí a la cristología, piénsese en SC 7 sobre la presencia de Cristo en la liturgia y SC 47: la Misa y el misterio pascual. También podemos citar en este sentido los famosos números de la GS 22: Cristo el Hombre Nuevo; GS 32: El Verbo Encarnado y la solidaridad humana; GS 45: Cristo, Alfa y Omega.

Pues bien, porque damos por supuestas esas enseñanzas, no recurrimos directamente a la cristología y a la pneumatología, para concentrarnos más precisamente en el objeto directo de nuestro estudio, la Trinidad, y no desviarnos por otros derroteros, legítimos sin duda, pero que nos 
podían apartar de nuestro verdadero propósito. Que prescindamos por razones de método de la cristología y pneumatología, volvemos a recalcarlo, no significa no reconocer su importancia en las enseñanzas conciliares o dejar de remarcar su trascendencia decisiva en la existencia cristiana y en la relación con el mundo. En los documentos tratados aparece claro que nada mejor que abandonarse a la actuación del Espíritu, para crecer en la espiritualidad y en la santidad de los hijos de Dios y de los hermanos del Reino. Pero hemos querido centrarnos en la Trinidad como tal, que confiere unidad y totalidad a todo lo relacionado con los pensamientos teológicos de cualquier signo. Cristología y pneumatología pueden ser tratados también en el interior de la trinitariología.

En muchos aspectos el pensamiento del Concilio procede de San Pablo. No hay más que ver las múltiples veces que aquél cita sus cartas. De ahí que en su teología y cristología aparece cómo Dios, Creador y Salvador, que en su día creó el mundo, y después del pecado humano, en Cristo lo regeneró. En la creación dio al universo y a la humanidad el ser, en la salvación puso de manifiesto la obra de amor, que procede del Padre por el Hijo en el Espíritu Santo. Dios no ha querido una humanidad profana, desligada de la trascendencia y un universo apartado de lo divino. Más bien ha deseado, y así lo ha realizado en Jesucristo, un hombre nuevo regenerado en Cristo, el hombre perfecto, a quien siempre hay que mirar $\mathrm{y}$ en quien hay que renovarse una y otra vez. Los problemas humanos encuentran su solución en "el único mediador entre Dios y los hombres: el hombre Cristo Jesús, que se entregó en rescate por todos» (1 Tim 2,5s), acreditado como «el Salvador del mundo» (Jn 4,42).

\section{LA TRINIDAD COMO FUNDAMENTO PROGRAMATICO}

Normalmente al inicio y al final de cada documento aparecen aseveraciones programáticas, en las que entra de lleno la Trinidad como el fundamento y la meta de cuanto se va a exponer. Los casos más significativos pueden ser las cuatro Constituciones y los Decretos sobre la actividad misionera de la Iglesia y sobre el ministerio y la vida de los presbíteros. Pero no sólo estos documentos, todos en realidad llevan el sello trinitario en el centro de su contenido. Según esto, no cabe duda que la Trinidad se encuentra en la base misma de las enseñanzas doctrinales del Vaticano II en su conjunto. Me parece bueno volverlo a recordar, ya que demuestra la alta cualificación teológica de la enseñanza conciliar. En este sentido ningún Concilio nos ha proporcionado una enseñanza tan sólida. Y lo ha 
hecho de forma descriptiva más que argumentativa, llevado por una intención netamente pastoral, más que doctrinal.

En la introducción de la Exhortación Apostólica Postsinodal «Verbum Domini», que tantos lazos de unión mantiene con las enseñanzas conciliares, el Papa emérito Benedicto XVI nos invita en el número 2 a reavivar el encuentro personal y comunitario con la Trinidad, sabiendo que participar en la vida de Dios, Trinidad de Amor, significa tanto como llegar a la alegría completa (1 Jn 1,4). Dios es Diálogo y desde el diálogo de amor con la Trinidad «podemos comprendernos mejor a nosotros mismos en la acogida del Verbo y en la docilidad a la obra del Espíritu. El enigma de la condición humana se esclarece definitivamente a la luz de la revelación realizada por el Verbo Divino» (VD 6). En el diálogo con la Trinidad la Iglesia desvela su propio ser: quién es, hacia donde se encamina y cuál es su auténtica misión en este mundo, tan necesitado de verdad, bondad y alegría.

\section{La IGLESIA familia del PADRE, CUERPo del HiJo humanado Y TEM- PLO DEL ESPÍRITU}

La orientación trinitaria destaca una y otra vez, de manera muy incisiva y penetrante, en el texto del para muchos más importante e influyente documento del Vaticano II, la Constitución Dogmática sobre la Iglesia. El que contenga la valoración de «dogmática» ya nos avanza mucho se du contenido preciso. El misterio eclesial, el pueblo de Dios, la jerarquía, los laicos y los religiosos adquieren toda su fuerza y significación de la eterna vitalidad de la Trinidad. No se puede llegar a la santidad y a la consumación escatológica, si se olvida su gracia salvadora, si no se entra en diálogo de amor con el Padre, el Hijo y el Espíritu. La Iglesia nació de la Trinidad y sólo puede encontrarse a sí misma y su puesto en el mundo en referencia permanente con su origen.

Pero hay algo más: No hay mejor manera de definir lo que en realidad es la Iglesia que recurrir a conceptos trinitarios como el Concilio hace en los números 2 al 5 de la Constitución. Volver a la Trinidad, brújula segura para orientarnos en la fe y en la vida cristiana, significa tanto como recuperar lo central de la identidad creyente; al mismo tiempo supone el mejor modo de llegar al hombre y la sociedad con un mensaje nítidamente espiritual y comunitario. El gran reto de los creyentes hoy consiste en situar a la Trinidad, acogida, sentida, vivida y testimoniada, en el puesto que se merece tanto en la Iglesia como en la sociedad, ya que tiene una 
incuestionable dimensión antropológica y social. Y el Concilio nos ha ayudado a ahondar en estas cuestiones vitales de modo muy significativo.

\section{LA DIMENSIÓN PASTORAL DE LA TRINIDAD}

De lo señalado hasta aquí se deduce que el Concilio presenta la teología trinitaria no de modo académico y estático, sino de manera descriptiva y dinámica, más apropiada al carácter pastoral, que mantienen todos sus documentos y tuvieron sus acertadas decisiones. No busca en modo alguno definiciones exactas de tipo dogmático, como pueden encontrarse en un tratado teológico, algo que además dejaría «fríos» a los creyentes. Más bien muestra a la Trinidad en el hacerse con los hombres: recreando a la Iglesia cada día, comunicándole incesantemente su gracia e invitándole a la misión desde la llamada al amor.

En el Concilio encontramos una tendencia clara a nombrar a las tres divinas personas en unos mismos contextos, que se diversifican de acuerdo con el tema abordado y con mucha frecuencia resaltan de muy diversas formas el desbordante amor divino. El Padre está en el origen; el Hijo realiza la obra de la salvación y el Espíritu alienta en la santificación mediante la vivencia de la comunión. Lo constitutjvo del amor trinitario consiste en lo dinámico, que se renueva continuamente. La Trinidad está en permanente comunicación directa con los hombres, expresando la entrañabilidad de su amor, renovado cada instante.

Sin duda se trata de una manera más adecuada de abordar la realidad trinitaria para el hombre actual, que tiene hambre del Dios vivo, no de definiciones doctrinales más o menos precisas. $\mathrm{Y}$ así, las personas divinas entran en permanente diálogo con los hombres, autodonándose en sus designios salvadores mediante un amor infinito y desbordante. La palabra «diálogo» jugó un puesto clave en los trabajos conciliares. Y esto fue debido al hecho de que los padres se dieron perfecta cuenta de que Dios no sólo es diálogo intratrinitario, sino también llamada constante a él en su relación amorosa con los hombres.

Tanto en la etapa peregrinante como en la triunfante la Iglesia no puede prescindir en modo alguno del continuo contacto con la Trinidad. Su referencia vital descansa en la presencia y actuación divinas en su seno. La Trinidad creó, acompaña por la senda de la historia y en su momento plenificará para siempre y de modo definitivo a la Iglesia y este hecho crucial y vital está llamado a convertirse en consciente percepción de su identidad más profunda, que nunca puede olvidar, so pena de hacerse traición 
a sí misma. La fe, el amor y la esperanza cristianos sólo pueden hundir sus raíces en la acción creadora, sanadora y consumadora de la Trinidad Santa.

\section{MISIÓN DE LA IGLESIA Y TRINIDAD}

Estrechamente vinculada a la Trinidad está la misión de la Iglesia. El texto evangélico clásico es Mt 28,16-20, que es recordado con relativa frecuencia en los documentos conciliares, sobre todo en la Lumen Gentium. Quizá sea el más citado de toda la Sagrada Escritura por sus repercusiones evangelizadoras. Toda la cita aparece dos veces en LG 19 y 22; las palabras del Resucitado que urgen a los once discípulos a la misión con todas las consecuencias en LG 8,17,24, GS 38, nota 13; AG 5: UR 2, nota 6; DH 13, nota 33; los dos versículos finales donde se menciona a la Trinidad en LG 8 y 24; DV 7, nota 1; AG 5; PO 4, nota 92; DH 1; 14 . El texto tiene un sentido trasversal, que pone de relieve su capital importancia.

Además estas frecuentes citas están declarando cómo la Iglesia tiene una conciencia muy viva del mandato dado por su Señor en los inicios de su andadura histórica. El Señor urge a sus discípulos a la imperiosa misión (Q 10,2 = Mt 9,37-38/ Lc 10,2) sin excusa alguna y sin vacilaciones cobardes (Q 10,3 = Mt 10,16/ Lc 10,3). La orden del Kyrios glorioso, entronizado ante la Trinidad Santa, ocupa desde entonces el centro de toda la actividad eclesial que se precie. Igual que existe la misión del Hijo y el Espíritu Santo en el seno de la Trinidad en salida hacia la salvación, también resulta inexorable la misión de la Iglesia, obediente a su identidad más profunda. Sólo poniendo en práctica el sagrado encargo confiado por el Resucitado la Iglesia católica podrá considerarse fiel a la Trinidad y obedecerá como debe a su Señor. Ofrezcamos este texto que no hemos presentado hasta ahora:

«Creemos que esta religión verdadera subsiste en la Iglesia católica y apostólica, a la cual el Señor Jesús confió la obligación de difundirla a todos los hombres, diciendo a los Apóstoles: "Id, pues, y enseñad a todas las gentes, bautizándolas en el nombre del Padre y del Hijo y del Espíritu Santo, enseñándoles a observar todo cuanto yo os he manda$d o "(M t 28,19-20) »(\mathrm{DH} 1)$.

Hay algo especialmente urgente hoy: la salida a la sociedad y al mundo para anunciar la buena nueva de la Trinidad salvífica, tal como nos la ha mostrado el Cristo, muerto por nuestros pecados y resucitado para 
nuestra salvación, y la que con tanta sinceridad, fuerza probatoria y testimonio creyente nos ha anunciado también el Concilio Vaticano II. Para respirar aire nuevo, necesitamos «salir fuera» de la Iglesia, para anunciar por los caminos de la tierra la buena noticia con el testimonio y la palabra, de que existe la Trinidad santa y buena, entrañable con los hombres. No hay nada más importante en la existencia humana, que experimentar a la Trinidad en la propia vida, porque es posible, gozoso y liberador hacerlo; porque llena a las personas de vida y consuelo. No hay tarea más urgente en la actualidad que esta: evangelizar a la sociedad y transmitir la fe a las nuevas generaciones, saliendo a las periferias del mundo, como acostumbra a repetir el Papa Francisco.

\section{LA TRINIDAD COMO MODELO DE ACTUACIÓN PARA LA IGLESIA}

La Trinidad, además de acicate para la misión, está llamada a ser modelo en la actuación de la Iglesia y de los creyentes en ella y fuera de ella. Constituye el espejo, donde tiene que reflejarse, para llevar una vida santa en todos los sentidos. Nada puede ayudar más a la Iglesia y a los cristianos que imitar el amor trinitario. De esta manera los creyentes entramos en la dinámica trinitaria, que siempre es presencia y actuación viva para la Iglesia y la sociedad, para el mundo y la creación, para los creyentes y las personas de buena voluntad, que desean dar sentido a su vida. No podemos vivir bien y ser felices, tendiendo hacia la plenitud, sin el aliciente trinitario, sin su actividad en nuestro interior, que nos sirve de modelo para nuestra relación con los semejantes. El Concilio nos hace conscientes de ello una y otra vez.

Pero hay algo aún más decisivo: Quien penetra en la pluriforme enseñanza conciliar sobre la Trinidad llega inexorablemente a la conclusión cierta de que Dios es Amor (1 Jn 4,8.16). Amor comunicado y entregado a los hombres como gracia y tarea. Las tres divinas personas, quintaesencia de lo que el amor tiene de más auténtico y genuino, constituyen la manera concreta cómo el Padre, el Hijo y el Espíritu Santo se muestran a la humanidad, para que cada hombre se realice en la relación pluridimensional del amor. El hombre es capaz de amor, porque la Trinidad le ha vocacionado para ello y le impele a ponerlo en práctica. Al final el amor es lo que salva, ya que es la realidad por antonomasia digna de fe. Esta es nuestra esperanza y confianza, amparada por la Trinidad Amor. Ese Amor con mayúscula es Padre, Hijo y Espíritu Santo. 


\section{LA CRISIS DE DIOS}

En su momento J. B. METz formuló esta tesis: «La crisis que ha afectado al cristianismo europeo no es principalmente, o al menos exclusivamente, una crisis eclesial. La crisis es más profunda: en efecto, no sólo tiene sus raíces en la situación de la Iglesia misma; ha llegado a ser una crisis de Dios». El Concilio quiso dar respuesta a esa crisis, cuando aún no había adquirido las preocupantes proporciones, que tiene en la actualidad. Y para ello situó a Dios en el punto de mira de sus intereses y en el blanco de sus actuaciones. Europa necesita recuperar su dimensión trascendente. Tiene que dejarse tocar por la mano amorosa del Padre, aceptar con gozo la salvación adquirida por el Hijo y guiarse por el Espíritu en la organización de la casa común para todos. De una cosa quiso que estuviéramos bien seguros, que «no hay prioridad más grande que ésta: abrir de nuevo al hombre de hoy el acceso a Dios, al Dios que habla y nos comunica su amor para que tengamos vida abundante» (VD 2).

Vivimos la fe cristiana en el mundo; la sociedad actual, sobre todo la occidental, necesita superar sus propios límites, ir más allá de sus resistencias religiosas, oyendo hablar de Dios de la forma y manera como el Concilio lo hace y dejando penetrar el amor divino en el corazón humano. El hogar de la humanidad es el mundo, lugar donde está llamada a resonar la buena noticia de la salvación, tan unida al Dios Trinidad. Los destinatarios privilegiados de la evangelización son las masas de personas, que no conocen a Cristo y sin embargo tienen en lo más recóndito de su intimidad hambre de salvación. Aquí se mueven los creyentes potenciales de la Iglesia, abierta especialmente a los hombres de buena voluntad y a los pobres necesitados de los bienes que sean. Nuestro comportamiento no puede consistir en alejar a otros de la fe trinitaria, sino llevar a ella, de modo que experimente de forma convincente la presencia y actuación de la Trinidad Santa entre los humanos.

\section{DE LA CRISIS DE DIOS A LA ALEGRÍA DE LA FE EN LA TRINIDAD}

Hay una tarea prioritaria hoy en la urgente misión de la transmisión de la fe: hacer posible con la ayuda de la gracia que los hombres de hoy logren pasar del «cansancio» y «eclipse» de Dios a la alegría de la acogida de la Trinidad y de su experiencia sentida. ¡Tenemos un Padre, que nos ama apasionadamente como a verdaderos hijos! ¡Contamos con un Hijo Humanado, nuestro Hermano, que murió y resucitó por nosotros y ahora vive en medio de nuestras fiestas y sufrimientos, mostrándonos que nada une más 
que los sufrimientos por los demás, ya que en ellos se refleja lo más fuerte del amor! ¡Nos inunda con su gracia un Espíritu Santo, que orienta nuestro existir y sostiene nuestra vida de hijos y hermanos del reino!

Los que componemos la Iglesia, como Familia del Padre, no podemos apartarnos de este centro. Estamos empeñados en reunir fuerzas espirituales, para hacer posible esta buena noticia en la vida personal y en el empeño comunitario a abrirnos a todas las personas de buena voluntad. Por aquí pasan y se concentran todos los esfuerzos evangelizadores. Sin esto nada está conseguido y todo puede perderse.

\section{LA INTERIORIZACIÓN DE LA TRINIDAD Y LA INHABITACIÓN DEL ESPÍRITU}

Desde las enseñanzas conciliares podemos afirmar que la fe no es otra cosa que la interiorización de la Trinidad mediante el encuentro salvador con Jesús y la inhabitación santificadora del Espíritu. En definitiva la fe consiste en la confianza incondicional en el Padre, tal como nos la ha mostrado y enseñado el Hijo humanado por la acción del Espíritu. La Trinidad ama al hombre hasta el punto de entregarle su propia caridad. Esta donación le capacita poder amar, acreditándose así como gracia, como vocación a ser desarrollada, nutrida y plenificada. El amor tiene que ver con la experiencia viva del obrar divino a favor de los hombres, que no sólo entienden la verdad del Dios Trinidad, como algo constitutivo para la realización de la Iglesia y de los humanos, sino también vive esa experiencia fundante con responsabilidad en la puesta en práctica del amor.

Jesús ha penetrado hasta el fondo en el amor incondicional del Padre hacia los hombres, nos lo ha expresado en sus parábolas y enseñanzas varias y nos lo ha mostrado con el testimonio de la propia vida. Jesús también ha penetrado en el fondo de la existencia humana y ha conseguido para la humanidad entera un nuevo espacio vital, que llega hasta la felicidad imperecedera. La vida eterna se origina, desarrolla y plenifica mediante la gracia plenificante de la Trinidad. Aquí echa sus raíces la esperanza cristiana. La Trinidad no puede arrumbarse así en el baúl de los olvidos, sino está llamada a convertirse en vida viva y verdadera en el centro mismo de la existencia cristiana.

\section{SEMPER CORAM DEO}

Al finalizar esta instructiva incursión a través de las enseñanzas del Vaticano II, queda meridianamente clara esta luminosa consecuencia: El 
seguidor de Jesucristo, de forma personal y la Iglesia en su conjunto, de forma comunitaria, todos los creyentes estamos llamados a vivir y conformar la propia vida coram Deo, delante de la presencia y actuación de la Trinidad Santa: acoger con gozo la voluntad amorosa del Padre bueno, realizarse con agradecimiento en la obra salvadora del Hijo humanado y experimentar mediante la acción de gracias las insinuaciones del Espíritu vivificante, de modo que la santidad adquirida mediante la gracia trinitaria, hecha de manera permanente don y tarea, se convierta en convincente testimonio ante la sociedad, para gloria de la Santa e Indivisa Trinidad. Aquí radica el corazón de todas las enseñanzas conciliares, llamadas a hacerse intensa vida cristiana hoy y siempre, experimentando la fe asimilada e intentando transmitirla.

Siguiendo sus orígenes trinitarios, la Iglesia está empeñada en la unificación de la humanidad en una gran familia de hijos y hermanos, dividida por el pecado tanto personal como social y estructural. En ella se realiza la renovación individual y la reconciliación universal, integrándose lo personal en lo comunitario y lo comunitario en lo personal y evitando así el egoísmo refinado y la deshumanización socializada. Aquí radica la obra salvadora, que la Trinidad lleva a cabo con la ayuda de la Iglesia. Aquí radica nuestro reconocimiento y exaltación del Padre, del Hijo y del Espíritu Santo en la vida propia y en la liturgia comunitaria, en la experiencia personal y en el testimonio público. Con memoria agradecida proclamamos que la Trinidad ha estado grande con nosotros. Queremos vivir a la Iuz de su resplandor, poniéndonos bajo su amparo santísimo.

La mirada a la Trinidad y su acogida en el propio corazón nos transmite grandeza de alma, para saber aproximarnos a las personas y aceptarlas tal como son, lo mismo que hace el Padre con cada uno de nosotros. El encuentro con la Trinidad nos lleva a la disposición, para realizar cosas grandes a favor de los demás, saliendo de uno mismo y abriéndonos a empresas que merece la pena realizar, cuando van dirigidas a pobres $y$ necesitados, a enfermos y dolientes, a pecadores y tambaleantes. 